\title{
論説
}

\section{宮城県追波湾及び附近の島に蕃殖する 二三鳥類について}

Notes on some birds breeding on the coast of Oppa Bay, Miyagi.

立花 繁信

Shigenobu Tachibana

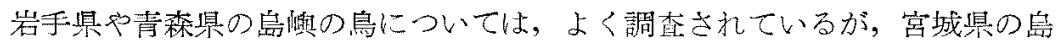

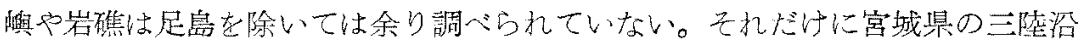

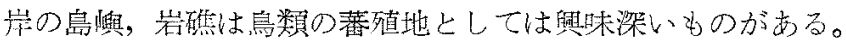

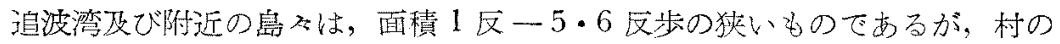
青年団の力によって蕃殖する悬類はよく保護され，宮城罢をも重要な地として この附近一带の沿岸と舅聺を保護区に指定し, ウミネコ・ケイマフリ・ハクセ キレイ等の保護它訂っている。特に双子島（3島よりなる）の秃には登攀不能 の鼻があり，これにはケイマフリ・ハクセキレイ・ウミネコ・アマツバメが蕃 殖している。面積も広く，東部は40 m の緦壁だが，頂部には赤土が深い。夏 李，ウトウ・ヒメウ・ウミウも観察され，蕃殖の可能性が充分考学られるので 最当洒值ある島である。

筆者は 1950 年以来，この地の鳥類の棲息状況や蕃殖について調查を進めて 来たが，荒天・濃霧・登攀不能にわざわいされ，又撮影中にカメラ落したり して，調查が行届いてない点が多い。しかし本年は，5月17日，5月27日，

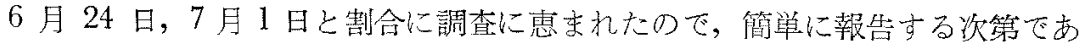
る。

ハクセキレイ Motacilla alba lugens Gloger

この地のハクセキレイの蕃殖については，故熊谷三郎氏により発表されてい る (1954) が，この附近の島嶼には極めて普通であって，どの島にも 3 ・4 番

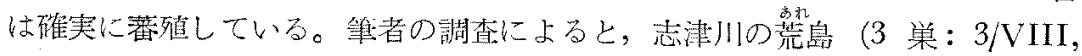

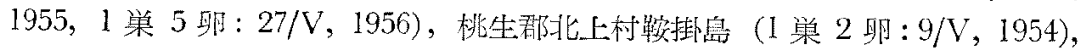


同松島（育敭中：1/VII，1956), 同双子島 (4 巣, 1 巣 5 卵：1/VII, 1956), 桃生郡河北町走少崎（育雛中：15/V，1653）等，いずれも海岸から $1 \mathrm{~km}$ 以内 の小島である。巣は岩地に生じたハイネズ Juniperus rigida Sieb et Zucc.

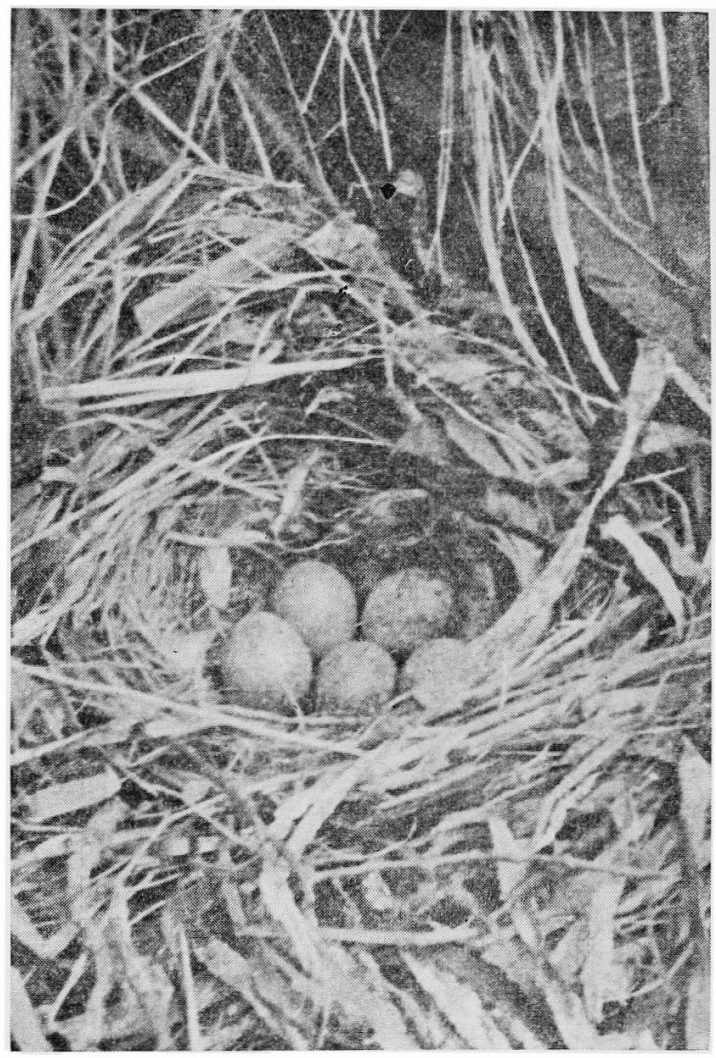

第 1 図 ハクセキレイの巣卵，主材はアマモで ある。 $(1956 \cdot 5 \cdot 27$ 宮城県本吉郡志津 川町荒島） Nest and eggs of Motacilla alba lugens in Miyagi.

var. conferta Makino の下や草間にあり，外径 $11-20 \mathrm{~cm}$ 内径 $6.5-8 \mathrm{~cm}$ 深さ 3-6 cm 高さ 7-23 $\mathrm{cm}$ 位。巣材は外部は禾 本科植物の枯れた茎葉を 主材に使うが，志津川の 荒島のものは，アマモ Zostera marina L. の打 上げられたのを使用して いた。産座にはどの巣に もウミネコの羽毛と細根 が用いられていた。12 卵 の測定は19.8-23.1 × 15.0 $-17.0 \mathrm{~mm}$ であった。卵 殼の色彩は, 志津川の荒 島のものは死褐の地に紫 褐玟点が一様に密在して おり，双子島のものは灰 青色の地に紫褐斑があ り, 鈍端に密在していた。 親鳥はセグロセキレイ Motacilla grandis より 告遙加に警戒性強く，抱 卵期，育雛期といえども 容易に人を近づけない。 卵期は上記の様に 5 月上旬一7 月上旬となっているが，8月 9 日に 4 雛づれ の親子を観察しているので7月一ぱいまでであろう(立花：1955)。なおこの附 近の小島には，七グロセキレイは全くみる事ができなかった。

アマツバメ Micropus pacificus kurodae (Domaniewski) 
本種は宮城県の内陸では天候の悪化して来た時に多く認められ，睛天の時は あまりみられない種類である。ただ，奥羽山脈中の熊野岳 $(1841 \mathrm{~m})$ の断崖に 蕃殖しているから，ての地方ではみら机る。かし，今まては本県内加巣畉 の発見は無かったらしい。これは，登る專が不可能な所に営巣している為と思 われる。三陸沿岸で腈天の日もみられるのは，睛れていても浮が荒れている為

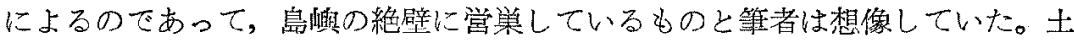
地の人達に聞くと“いそつばめ”なら双子島に沢仙るとの事たっった。“いそ つばめ”が何種なのか甚だあいまいなので，或はミウッバメの類ではないかと 期待していた。先年 5 月 8 日には双子島には認められなかったので多少の不安 むあったが，1956 年 7 月 1 日に棲息してないといわれる双子島中真中のの島 に上陸して，たらまち6 巣を発見したが，これはアマツバメであった。いずれ 抱卵中であり，近寄っても逃げようとせず，じっとしているが，手を伸ばす とやっと腰を上げ，奥の方へ逃れるが龙卆様なことはしない。これは翼がつか えて飛べなからたと思われる。岩壁に精栄したり，樂を粘着したものは全く

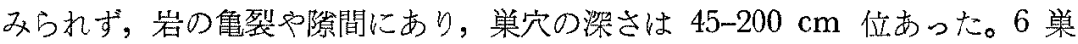
の測定は外径 9-13 cm, 内径 7.5-9 cm, 梁さ $1 \mathrm{~cm}$ 位，高さ $1.5 \mathrm{~cm}$ 位で，巣 材は禾本科植物とウミネコの羽毛を混ぜ合せ，固く締っている。6 巣中に卯化 後5日位の2雛が入っているのが1栄むったが，他は 3 卵のもの4巣，2卵の

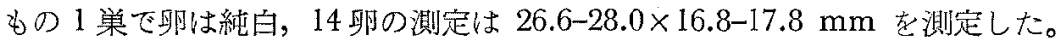
卵は5月 8 日にみられなかったので，この6集より推定すると，卵期は6月一

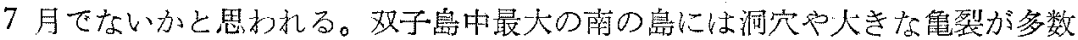
あるので濃霧の中を数 100 羽の群が乱舞していた。

なおこの島の対岸の小滝という部落にはアマツバメが人家に賞巣していると いう。未だ調查してない力゙可能性はある。

\section{ジイサギ N.n. nycticorax (Linné)}

鞍掛島には 1000 番位のウミネコと100 番以上のゴイサギが混槙繁殖してい る。小高い所から島家眺かると，成鳥に混じって沢川の星五位力゙岩上や八イネ ズの枝上に止っている。陸から鼻までは $6 \mathrm{~m}$ 位しかないので梯子を掛けるが， その時，飛制可能のゴイサギは一斉に離島して，人が去らねば帰らないが，ウ ミネコは近奇らなければ飛び立たず，飛び立っても遠くへは行かずすく舞い飠 る。

6 月下旬に充分成長を遂げ，採作も自由なものもあれば，巣立直後のものも

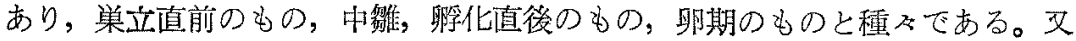


各巣の雛の発育も不斉で 1 雛位ずつ極めて遅れたものが観察された。卵期の 16 巣について調査したところ，卵数は 3-4 個のものばかりであった。この島のゴ イサギは，ハイネズやマサキ Euonymus japonica Thunb. の枝上に営巣し，

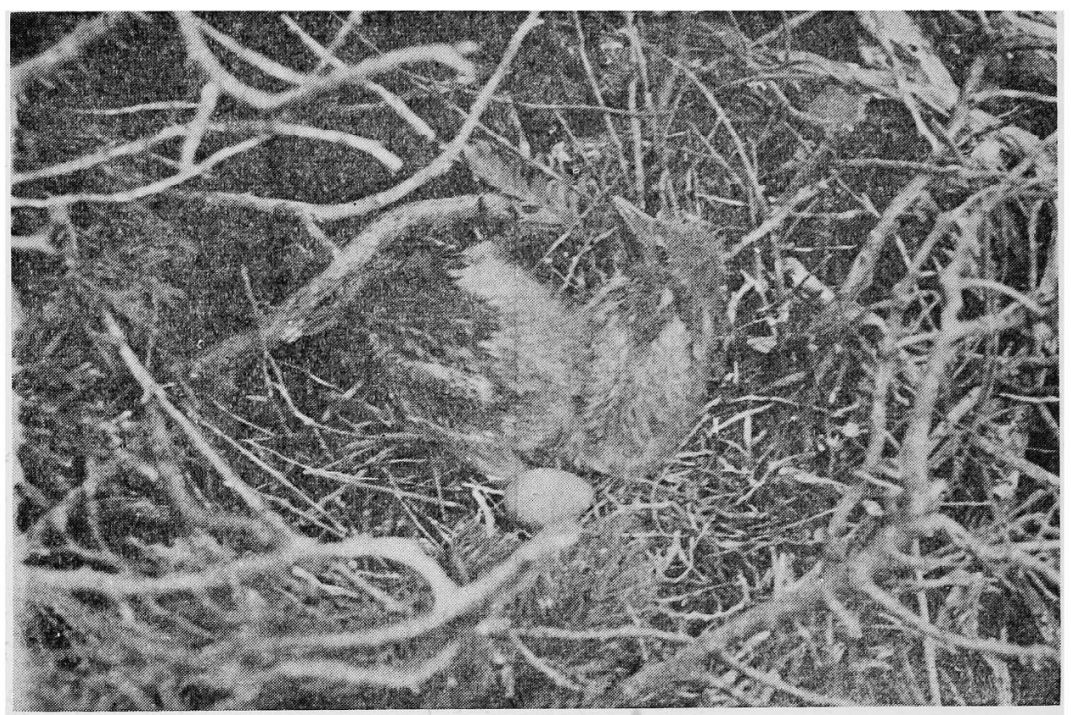

第 2 図 ハイネズの根際の地上の巣のゴイサギの雊＼cjkstart栄中の卵及び习习毛は ウミネコのもの。(1956.6.24 宮城県桃生郡北上村鞍掛島） Chicks of the Black-crowned Night Heron in the nest on the ground, Kurakake I.

高さは $50 \mathrm{~cm}$ 以下で，地上営巣のものも $30 \%$ に達し，ウミネコの巣にすぐ隣 あっているものもあり，中には，ウミネコの無精卵が㒛のいる巣内に転がって いたのもみられた。雊は脚が丈夫なので，人の姿を認めると相当のスピードで ハイネズの下をくぐりながら逃げる。孵化後, 間もないものは歩けないので, 巣内にうずくまってはいるが，枝の下に頭支入れ眼ばかり出して様子をうかが う。食性は海産動物は全くみられず，アカガエル Rana japonica Guenther や カナへビ Takydromus tachydromoides (Schlegel) 等がみられた。

\section{ウミネコ Larus crassirostris Vieillot}

松島・胴島・蹄島・鞍掛島・双子島に蕃殖し, その総数 3 万羽という。松島 には数本のアカマツ Pinus densiflora Sieb. et Zucc. が生えているが，他は $1 \mathrm{~m}$ 以下の灌木を僅かに見るだで，特に胴島・蹄島には，不本科植物 Gramineae・カヤツリ草科 Cyperaceae の植物が少し生じているだけで，殆んど 
粘板岩が裸出してみえる岩礁である。天然記念物に指定されている江の島列島

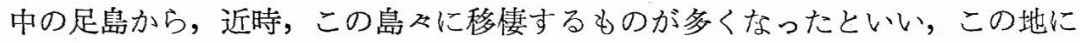
定住するものも少数認められる。これらの島くを合せても足島の面積よりも狭

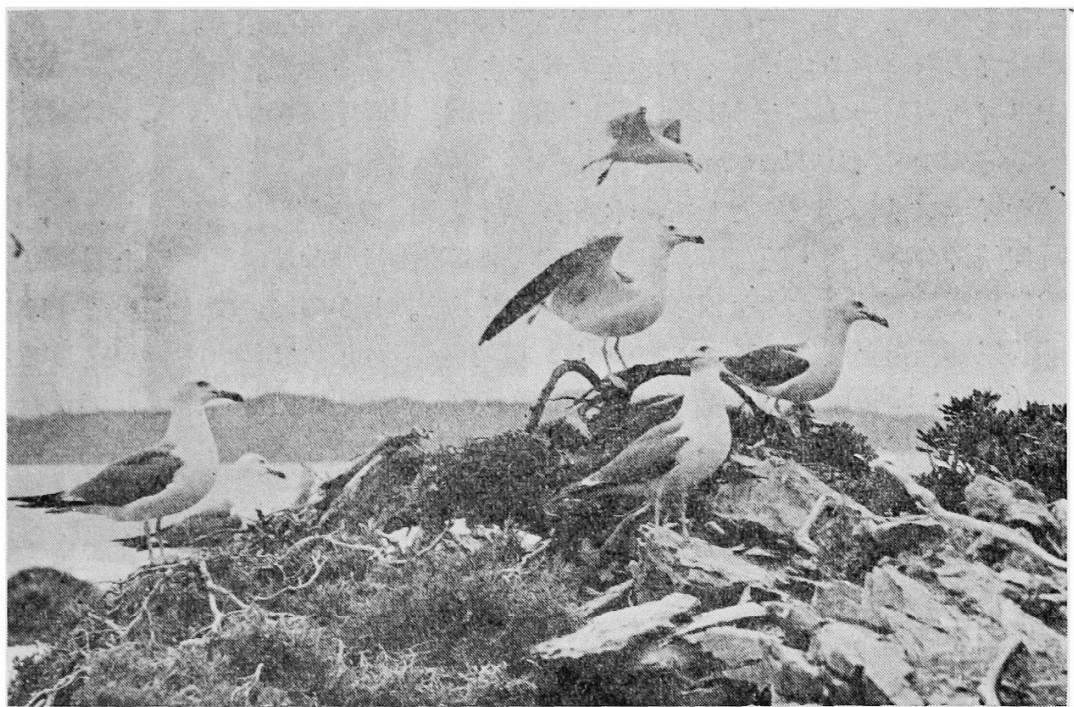

第 3 図 鞍掛島頂上のウミネコ（この島でウミネコとゴイサギが混棲してい る) $(1956 \cdot 6 \cdot 24)$ The Black-tailed Gulls on the top of Kurakake I.

く，巣材も遥かに少ないが，密度は大である。卵期は 4 月下旬一6月上旬で， 6 月下旬 $(24 / \mathrm{IV}, 1956)$ に入と卵は殆んどみられず，2 卵・4 卵の 2 巣を発 見し得ただけであった。変ったところではオリーブ色の無斑卵を観察した。

5 月中旬頃より多数群れて追波川を遡上し，水田に下り慨を漁る。これは水 田に撒いた魚粕を食う為だと大いに農家の激怒を買った。確かにそれらしい所 作むあるらしく観察された。しかし，本年は水田に全然魚粕を使用しないが， やはり，多数舞下りて例年の如く摂食していた。これは代搔の為に弱って浮い た土中・氷中の生物を漁るためだろう。1956 年 6 月 3 日に志津川の田中完一 氏が双子島を小舟で調杳中, タカ(種名不詳)とウミネコの格斗を詳しく観察さ れたそうである。筆者も 7 月 1 日に松島でトビ Milvus migrans が雛をさ らったのをみているが，島々に居るウミネコが一斉にパッと舞上り，大声で 沜き立てた。東方 $500 \mathrm{~m}$ 位の所にトビの姿が認められた。島上でぐるぐると輪 を描いた時，ウミネコは叫びなが西方へ逃れ去った。間髪を入れず，サッと舞 
下り知倠をつかみ去ったが，この時，引返したウミネコはクウァクウァーと鳴き ながら息って行った。

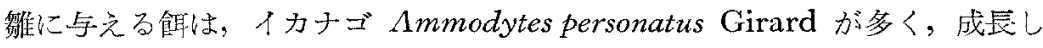

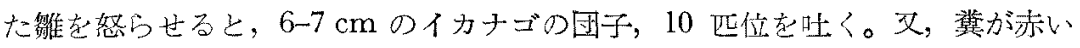
のはイ力在食へる為た，イ力の軟骨加多数の看にみられた。中には $18 \mathrm{~cm} の$ ヤリイカ Doryteuthis bleekeri Keferstein 圭昍いたるのもあった。

\section{ケイマフリ Cepphus carbo (Pallas)}

ケイマフリの蕃殖地として，本州からは青森県下北郡九艘泊沖の升天島，同 尼屋崎沖の弁天島・阿部崎，岩手県下閉伊郡崎山村姑子崎，岩手県上閉伊郡三

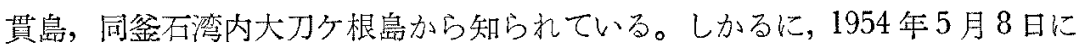
熊谷三郎氏らと共に双子島に稓いて 1 卵を発見し， $64 \times 45 \mathrm{~mm}$ 孛測定してい る(熊谷: 1956)。巣は岩石の間隐にあり梁さ $35 \mathrm{~cm}$ 位だった。1956年7月 1 日，この奴子島の真中の島に上陸し，観察したが登るのが精一ぱいで，巣卵の 発罗もむったが，断崖であり，相当の樑さのところなので，測定も撮影もてき なかった。南の島には，磪実に数番が蕃殖して居り，育雊中のもの少なくとも 2 番はあり，慨を運搬しているのを観察した。産卵期は 5 月上旬一7月上旬ま では確実であるが，恐らく7月一ぱい位だと思われる。韓国では4月一5月樺 太・千島ては 6 月一7月が知られている（清棲：1952）岩上に休を場合は躒䟢 までつけて体を立てているが，飛び跳称る時は雨足を揃光，趾を使用し，なか なか速いものである。岩上で鳥く時は真赤な口中が解かにみえる。

\section{文 献}

熊谷三郎 八タ七キレイの新蕏殖地 野鳥 19 (5)：49-50，1954

立花慗信 鳥声䉼片 (II) 野鳥 20 (I) : 69, 1955

清楚幸保 日本鳥類大四鑑 III pp. 840-841， 1952

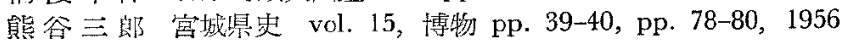

\section{Résumé}

Observations on the following breeding birds are reported:

Motabilla alba lugens Breeds may to July on the islands: Are, Kurakake, Matsushima, Futago and Hashirigasaki on Shizugawa Bay coast. Its nest material is the seaweed, Zostera marina L.

Apus pacificus kurodae Breeds on Futago Is. The egg dates are June to July.

N. n. nycticorax Beeds on Kurakake I. together with Larus crassirostris. It Nests at the height not more than $50 \mathrm{~cm}$. from the ground and $30 \%$ of the nests were found on the ground.

Larus crassirostris Estimated as thirty thousand, breeding on several islands. Lays eggs from middle April to early June. The chicks often taken by kite.

Cepphus carbo Breeds on Futago Is., laying eggs during May and July. 